\title{
Essais
}

ESSAIS

Revue interdisciplinaire d'Humanités

Hors-série 4 | 2018

Stanley Kubrick

\section{Stanley Kubrick at the Interface of film and television}

Matthew Melia

\section{(2) OpenEdition \\ 1 Journals}

Electronic version

URL: http://journals.openedition.org/essais/646

DOI: 10.4000/essais.646

ISSN: 2276-0970

Publisher

École doctorale Montaigne Humanités

Printed version

Date of publication: 1 July 2018

Number of pages: 195-219

ISBN: 979-10-97024-04-8

ISSN: 2417-4211

\section{Electronic reference}

Matthew Melia, "Stanley Kubrick at the Interface of film and television », Essais [Online], Hors-série 4

2018, Online since 01 December 2019, connection on 16 December 2019. URL : http://

journals.openedition.org/essais/646; DOI : 10.4000/essais.646 


\section{Stanley Kubrick at the Interface of film and television}

\section{Matthew Melia}

During his keynote address at the 2016 conference Stanley Kubrick: A Retrospective ${ }^{1}$ Jan Harlan ${ }^{2}$ announced that Napoleon, Kubrick's great unrealised project ${ }^{3}$ would finally be produced, as a HBO TV mini-series, directed by Cary Fukunaga (True Detective, HBO) and executively produced by Steven Spielberg. He also suggested that had Kubrick survived into the $21^{\text {st }}$ century he would not only have chosen TV as a medium to work in, he would also have contributed to the contemporary post-millennium zeitgeist of cinematic TV drama.

There has been little news on the development of the project since and we are left to speculate how this cinematic spectacle eventually may (or may not) turn out on the "small screen". Alison Castle's monolithic edited collection of research and production material surrounding Napoleon ${ }^{4}$ gives some idea of the scale, ambition and problematic nature of re-purposing such a momentous project for television. In the introduction to the collection Harlan writes:

For Kubrick, Napoleon offered a chance to make a big epic film on sweeping subjects: an important episode in European history ${ }^{5}$, a compelling personality, a unique historical figure, a tale that embraces glamour, revolution, romance, envy, intrigue and betrayal, battles on land and sea, and above all power. It was

1 De Montfort University, Leicester, UK, 11-13 ${ }^{\text {th }}$ May 2016.

2 Stanley Kubrick's producer, brother-in-law, and spokesman for the Kubrick Estate 1.

3 Originally intended for release in the wake of 2001: A Space Odyssey, it was beaten to the punch by Sergey Bondarchuk's 1970 film, Waterloo, starring Rod Steiger.

4 Alison Castle (ed.), Stanley Kubrick's Napoleon: The Greatest Movie Never Made, Köln, Taschen, 2011.

5 The serialised World War II HBO docu-drama Band of Brothers (2001) a landmark piece of television, executively produced by Spielberg, similarly dealt with "an important episode in European [Military] History" from a globally expansive and televisually ambitious perspective may offer a framework for understanding how the HBO Napoleon could turn out. Spielberg, of course, has form when it comes to bringing to life Kubrick's unrealised projects, with the 2001 film, A.I.: Artificial Intelligence. 
a chance to portray all of Europe and North Africa -from Lisbon to Moscow, from the dry deserts of Egypt to the snowy wastes of the Russian Steppes- in an era of upheaval ${ }^{6}$.

In a 1969 interview with Joseph Gelmis (in the same collection) Kubrick discusses plans for staging the film's intended battle sequences and their projected scale:

We're now in the process of deciding the best places to shoot, and where it would be most feasible to obtain troops we need for battle scenes. We intend to use a maximum of forty thousand infantry and ten thousand cavalry for the big battles which means that we have to find a country which will hire its armed forces out to us -you just imagine the cost of fifty thousand extras over an extended period of time. ${ }^{7}$

Once, the limited scope and dimensions of the home TV set, and the economic limitations of TV production would have made such a project impossible. With $21^{\text {st }}$ century advances in home televisual technology ${ }^{8}$, new broadcasting technologies and the epic production scale of contemporary programming (from documentary to drama), television as a cultural medium is once again challenging the cultural dominance of cinema, and is increasingly up to the task of accommodating such an enormous project as well as the vision of a director synonymous with expansive cinematic spectacle and idiosyncratic design: HBO's monolithic flagship fantasy series Game of Thrones (for instance) recently included comparatively similar epic battle sequences of the size and scale envisioned by Kubrick for Napoleon, one battle sequence ${ }^{9}$ in the serial using only 500 extras digitally reproduced and replicated in their thousands ${ }^{10}$.

The centrality of television to Kubrick's work has so far been critically overlooked and few studies have been dedicated to the "tele-centricity" of the films. The hope of this study is to examine Kubrick's own position at the interface of the two mediums. I aim to illustrate the "tele-awareness" of Kubrick's cinema, suggesting that as the scope, ambition of contemporary television programming has widened Kubrick's films are becoming more than just a point of knowing iconographic homage and pastiche but that the language of his cinema (stylistic, thematic, formally, in design) is increasingly becoming a referent and part of the new $21^{\text {st }}$ century cinematic language and vernacular of television itself.

6 Jan Harlan, “Stanley Kubrick's Napoleon", in Alison Castle (ed.) Stanley Kubrick's Napoleon: The Greatest Movie Never Made, Köln Taschen, 2011, p. 15.

7 Joseph Gelmis, "Kubrick talks about Napoleon", in Alison Castle (ed.) Stanley Kubrick's Napoleon: The Greatest Movie Never Made, Köln: Taschen, 2011, p. 43.

8 The displacing of the TV itself within the domestic space with "Home cinemas".

9 "The Battle of the Bastards", S9E6, broadcast: 19/6/2016.

10 Megan McClusky, The Astounding number behind Game of Thrones "Battle of the Bastards", 2016. www.Time.Com, http://time.com/4372304/game-of-thrones-battle-of-the-bastardsnumbers/. Last viewed: 01/11/2017. 
Contemporary criticism is only starting to engage with the director's presence in $20^{\text {th }}$ and $21^{\text {st }}$ century television. Mick Broderick ${ }^{11}$ has, for instance, recently charted the history and presence of Kubrickian homage, pastiche and the "Auteurist influence" of Kubrick in the long-running animated sitcom The Simpsons. ${ }^{12}$ Later I will illustrate how televised animation also plays a role in the latter half of Kubrick's own career: in The Shining (1980). Full Metal Jack (1986) and Eyes Wide Shut (1999) where TV cartoons are associated with corruption of innocence, the loss of childhood and the dissolution of family.

\section{Furthermore Robert Kolker writes:}

Homer and Bart Simpson have been dreaming themselves into 2001 and $A$ Clockwork Orange for some time. Still, the infiltration of Kubrick's images into popular culture is not exactly the same as influence. And none of it is the same as the deep seepage of, for example, the Hitchcockian design into Martin Scorsese's work, or even the Fordian fantasies of homestead into Spielberg's. Many filmmakers try to make Hitchcockian or even Fordian films. No one sets out to make Kubrickian films. They are completely boxed in by an inimitable style and an intellectual complexity that is impossible to duplicate or recreate. ${ }^{13}$

Later I suggest that television is becoming a space where Kubrick's cultural influence is increasingly being felt; where contemporary "quality" television drama not only homages and pastiches but also shows a "deep seepage" of "spectacular" Kubrickian design and style in the architecture, design and space of global auteurist TV dramas, such as Westworld (Nolan, HBO, 2016), Hannibal (Fuller, NBC, 2013-15) and The Young Pope (Sorrentino, Sky Atlantic, Canal+, 2017) ${ }^{14}$ : television which Helen Wheatley would describe as "Spectacular":

It is programming which is designed to be stared at, to be ogled, contemplated and scrutinised, to be gaped at and gawked at. It is programming that absolutely conforms to (at least in part) to the Oxford English Dictionary's definitions of spectacle as both "a visually striking performance or display" and "an event or scene regarded in terms of visual impact" or to Geoff King's definition of spectacle as "the production of images at which we might wish to stop and stare". It is the image on the television which holds the viewers gaze and which, if only for a moment, can be appreciated outside of the drive of the narrative. ${ }^{15}$

11 Film scholar and author and authority of Kubrick's Dr Strangelove, or How I Learned to Stop Worrying and Love the Bomb (1964).

12 Mick Broderick, "Animating Kubrick - Auteurist Influences in The Simpsons", Screening The Past ("Post Kubrick Dossier"), Issue 42, October $4^{\text {th }}$ 2017, Melbourne, LeTrobe University. http://www.screeningthepast.com/2017/09/animating-kubrick-auteur-influences-in-the-simpsons/. Last Viewed: 05/03/2018.

13 Robert Kolker, "Rage For Order: Kubrick's Fearful Symmetry", in Raritan: A Quaterly Review, Summer 2010, Vol. 30 (1), p. 53.

14 For the purposes of this discussion and for expediency's sake I have chosen to focus on contemporary "quality" television drama rather than other forms such as documentary or popular entertainment shows.

15 Helen Wheatley, Spectacular Television: Exploring Televisual Pleasure, London: IB Tauris, 2016, p. 1-2. 
TV sets also have a significant presence in Kubrick's films serving a number of purposes; the watching of television is a recurring act. Broadcasting, television and the televisual are part of the intertextual matrix of Kubrick's cinema, which Rod Munday terms the "Kubrick Cinematic Universe"16. The Shining, for instance, proves to be the most televisually rich of the films and makes a useful comparative paring with Eyes Wide Shut, in which there also moments where the TV set has a significant presence, this film also adopts an aesthetic televisual "identity".

While my research at the Kubrick archive has uncovered no specific interviews or correspondence where the director directly articulates any thoughts on the medium or its technological potential ${ }^{17}$ the Kubrick archive does contain a number of production materials (continuity scripts; early script drafts and treatments) which reveal redacted TV-centric dialogue; design research, etc. and illuminate the role and immersion of television in Kubrick's cinema and help shed light on and reveal not only Kubrick's own interest in the medium of television (particularly as self-reflexive device) but also an apparent ambivalence and scepticism towards it.

\section{Television In Kubrick}

The Stanley Kubrick Archive houses a transcript of a speech, given in 1965 to a cohort of journalism students at the University of Indiana by Elmer Lower, then President of ABC News. This speech celebrated the influence of science fiction writer, Arthur C. Clarke over the evolution of "Global television", broadcast communication and satellite technology. He identified Clarke's article, "The Future of Communications" (Wireless Magazine, October 1945) ${ }^{18}$ as a pivotal and prophetic moment which foresaw the genesis of the synchronous communications and anticipated (the then recently launched), "Early Bird"19:

16 Rod Munday, A Kubrick Cinematic Universe, in Vincent Jaunas and Jean-François Baillon, "Stanley Kubrick. Nouveaux horizons". Bordeaux: Essais, hors série, 2018, p. 135-150.

17 The archive does contain a large amount of documents relating to the television marketing of Kubrick's films: a letter from Kirk Douglas for instance, dated $13^{\text {th }}$ April 1959, proposing a "television spectacular" around the release of Spartacus as well as documentation and research materials for "TV-Spots". The television marketing of Kubrick's films, however, will form the subject of a later study and for expediency's sake have been omitted from this discussion.

18 This scientifically complex and mathematically dense article was editorially retitled to "ExtraTerrestrial Relays: Can Rocket Stations Give World Wide Radio Coverage?”, for publication.

19 "Early Bird" was the first International geosynchronous commercial communications satellite or "Intelsat 1", launched from Cape Canaveral on Tuesday, 06 April 1965. J. Terry White describes it: "Though primitive by today's standards, Early Bird functioned well its role as a communications satellite. Among its many accomplishments, the satellite helped make possible the first live television broadcast of the splashdown of a manned spacecraft when Gemini 6 returned to earth in December of 1965. Early Bird was deactivated in January of 1969" (J. Terry White, "Early Bird Satellite Launch", White Eagle Aerospace, 2012. http:// www.whiteeagleaerospace.com/early-bird-satellite-launch/. Last viewed: 19/11/2017). 
Clarke did predict synchronous communications satellites in an article he wrote for the British magazine Wireless World under the title "The Future of Communications". The Article envisioned a communications network using satellites whose orbital speed is synchronised with the earth's rotation, a system in which three space stations, arranged equidistantly above the earth, could cover the globe. It theorized that if a rocket could reach a speed of 5 miles a second, it could continue to circle the Earth indefinitely like a second moon... All of the electrical energy needed to run the relay stations, according to the article, could come from the Sun... One thing that the 1945 Clarke article did not foresee was that the satellites would be unmanned... Up to this point, the communications satellites could not transmit images. ${ }^{20}$

This discussion of Clarke's work provides a context for understanding and interrogating the presence of the televisual in Kubrick's films which deal imaginatively and iconographically, with the transmission and reception of a "Wireless" broadcast signal; broadcasting and receiving bodies and the relay and transmission of images. The transmission and relay of the "broadcast image" is embedded within the narrative of the films at an inter and metatextual level: Kubrick scholar Rod Munday has observed how Kubrick's films offer a matrix of intertextuality, exhibiting a communicative relay of images ${ }^{21}$. Munday noted (for instance) how the violent battle between the hominids at the start of 2001: A Space Odyssey is relayed and restaged in the fight between Alex's Droogs and Billy Boy's gang in A Clockwork Orange (1971), Kubrick's next film. Within this "Universe" television casts a mesmerising, hypnotic, controlling spell and exists in close (often physical) proximity to the break up and dispersal of the family unit and the collapse of familial communication [see discussion below regarding both The Shining and Eyes Wide Shut (1999) where this is iconographically expressed and where the television itself becomes a literal barrier between family members]. Clarke's speculative and somewhat utopian view of the "future of communications" is therefore set in tension with Kubrick's own more ambivalent relationship to the medium.

The synchronised wheeling, orbiting astral bodies of 2001: A Space Odyssey's space ships and stations recall the orbiting satellites of Clarke's vision, Strauss's "Blue Danube" conjures a sense of river-like flow and relay. Clarke's communicative satellites are also recalled in the Danny/Halloran relationship in The Shining and in the way Danny, Wendy and Jack become similar detached bodies in the cavernous, maze like space of The Overlook: receptors for images "broadcast" and projected by the hotel itself (see below).

David Pescovitz argues that not only are televisions narratively present in 2001: A Space Odyssey, they were also present at the conceptualisation of the text. In an early draft of the novel from which the film emerges ${ }^{22}$ (a collabora-

20 Stanley Kubrick Archive, University of the Arts, London, ref. no. SK/12/8/2/55.

21 Rod Munday, op. cit., 2018, p. 135-160.

22 Housed at the Clarke archive in the Smithsonian National Air and Space Museum. 
tion between Clarke and Kubrick ${ }^{23}$ ) the alien artefact the hominids encounter was imagined as a glowing television-like cube rather than the film's enigmatic black Monolith. Citing Bruce Sterling ${ }^{24}$ he states:

As they worked together, conjuring up the novel and the film, correspondence reveals a pre-occupation with "the Cube" (later transmuted to "The Monolith"). Responding to Clarke's suggestion in 1966 that the cube communicates directly with the man-apes who would populate the film, Kubrick instead advocated a more enigmatic presence: "We see only the hypnotic image and the spellbound faces of the apes. ${ }^{25}$

Watching or gazing is Kubrickian trope and with the troubling, invasive and enigmatic "Kubrick Stare" characters repeatedly look beyond the screen boundary into the audience space. In 2001: A Space Odyssey the celestial and hopeful (according to Peter $\mathrm{Kramer}^{26}$ ) gaze of the Starchild into the camera is relayed and challenged in the opening shot of $A$ Clockwork Orange with Alex's conversely malevolent stare beyond the fourth wall (Figure 1). Barry Keith Grant reminds us that:

In Kubrick's cinema, eyes figure prominently as images of vision and perception, or the lack of it. A Clockwork Orange features numerous close ups of Alex's eyes, first in droogie garb with make-up and eyeball cufflinks and later when his eyes are propped open during the Ludovico technique. Kubrick's last film, completed just before his death shows people blinded by the quotidian world, entrapped within their own egos with "eyes wide shut". ${ }^{27}$

In Kubrick's films television is an "enigmatic" and suspicious technology which controls the viewer and holds them "spellbound" (not unlike the Monolith in that regard). During the "Ludovico treatment" sequence in $A$ Clockwork Orange Alex is physically restrained and unable to look away from

23 Kubrick scholar, author and 2001 expert Simone Odino offers a comprehensive analysis of the relationship between the two in his paper "Dear Arthur, What Do You Think? The ClarkeKubrick Collaboration on 2001: A Space Odyssey and A.I. from their Letters from the Smithsonian" (paper delivered at the conference Stanley Kubrick: Nouveaux Horizons, Université Bordeaux Montaigne, 17/05/2017).

24 Bruce Sterling, Personal Writings of Arthur C. Clarke Reveal the Evolution of 2001: A Space Odyssey. Smithsonian.com: https://www.smithsonianmag.com/smithsonian-institution/personal-writings-arthur-c-clarke-reveal-evolution-2001-space-odyssey-180954967/, May, 2015. Last Accessed: 17/02/2018.

25 David Pescovitz, 2001's Monolith was Originally "The Cube" BoingBoing. https://boingboing. net/2015/04/29/2001-a-space-odysseys-mon.html, April 2015. Last Accessed: 17/02/2018.

26 At 2018 during the Inaugural Stanley Kubrick Lecture, London Community College, University of the Arts, London, Kramer suggested that the final shot of 2001: A Space Odyssey, signified both a rebirth and hopeful fresh start for humanity. This paper argues that this view is countered by the next film A Clockwork Orange, and the malevolence of Alex's stare into the camera.

27 Barry K. Grant, "Of Men and Monoliths: Science Fiction", Gender and 2001: A Space Odyssey, in Robert Kolker (ed.), Stanley Kubrick's 2001: A Space Odyssey, NYC, OUP USA, 2006, p. 112-113. 
the bombardment of violent, extreme images to which he is being forcefully subjected $^{28}$ (Figure 2). Here the broadcast, televisual image is appropriated by the state as a mode of Pavlovian control and brainwashing. ${ }^{29}$

During the "World Tonight" sequence in 2001: A Space Odyssey the viewer observes Bowman and Poole as they sit to breakfast (Figure 3), each absorbed in his own televised image, broadcast back via the screens of their proto-iPads. They are watching an interview recorded and broadcast by the BBC via satellite link up between Earth and Space. As they do so each seems acutely unaware and unresponsive to the other's presence, "spellbound" and transfixed by the self-image on-screen. Interviewer Martin Amer opens the interview and documentary by declaring:

The World Tonight recorded an interview with the crew of the Discovery at a distance of eighty million miles from earth. It took seven minutes for our words to reach the giant spacecraft but this time delay has been edited from the recording.

An examination of the archived continuity scripts used during the films production reveal further TV-oriented dialogue redacted from the finished film (and which was to come after the above sequence):

Bowman: "Well I thought that went reasonably well".

Poole: "Yes, I thought I was a bit grim. I usually am on television".

Bowman: "You know they always cut off all the best answers".

Poole: "Yes, but you can always count on them asking all the same questions can't you?".

HAL: "The favourite question seems to be the one about why the mission was advanced 5 years". ${ }^{30}$

Martin Amer's proclamation that they have edited the 7 minutes time delay from the recording self reflexively calls to mind the dramatic (and cinematic) jump cut between pre-historic bone and spaceship at the start of the film: an edited time delay of several million years. The mechanics of cinema and television are aligned and Television is presented as part of the evolution of cinema: an idea borne out by the current milieu of cinematic "spectacular" ${ }^{11}$ television

28 This image may be seen reflected in the staging of Samuel Beckett's, 1973, production of Not I at the Royal Court and the way in which actress Billie Whitelaw was physically restrained for the performance. A reading of Beckett in Kubrick will, however, be the subject of a later study.

29 In the first episode of the podcast, The International Anthony Burgess Foundation Graham Foster suggests that this has its roots in author Anthony Burgess's familiarity with the text The British Way and Purpose: a collection of essays/textbook used by members of the education corps in teaching student soldiers abroad the way of the "responsible citizen" as well as the formative influence of Huxley's Brave New World Revisited (1958) and it emphasis on social conditioning, totalitarianism and Pavolvian control.

30 Stanley Kubrick Archive, University of the Arts, London, ref. no SK/12/3/4/3/19.

31 Helen Wheatley, Spectacular Television: Exploring Televisual Pleasure, London, I.B. Tauris, 2016, p. 1-2. 
(Section 3 of this discussion). During the World Tonight sequence Kubrick's film camera adopts the "persona" of a television documentary camera training itself sequentially on parts of the ship, in a montage, as they are discussed by Amer. TV becomes a mirror for film, a medium within a medium. The TV/Film relationship is another Kubrick double like doubling Alice Harford and daughter Helena in Eyes Wide Shut in front of the bathroom mirror or Bowman and Poole at the start of the sequence:

Not only does Kubrick choose two actors with significant physical resemblances, but he repeatedly places them in visual or comparative contexts that create a mirroring effect: Bowman is left-handed and Poole right-handed, and both eat the same food while narcissistically watching, on separate newspad screens, a BBC telecast (ironically titled "The World Tonight") where their images, along with HAL's eye, are duplicated. ${ }^{32}$

However, the redacted exchange Kubrick's possible concern with TV's ability to edit and manipulate the truth. Kubrick exposing human insecurities about the self and identity when reflected back, translated and filtered through the medium of the screen, aligning with the films obsession with artificial intelligence, human design and identity.

Further redacted dialogue from the continuity scripts, reveals other key changes: when Amer asks Bowman if HAL is capable of genuine emotional response he responds:

As far as I'm concerned HAL has feelings and emotional responses and for all practical purposes IS a human being. ${ }^{33}$

In the finished film's dialogue Bowman responds that it would be impossible to make a judgement on such an issue. Ironically Bowman and Poole elicit few emotional responses during the film but especially, seemingly, when caught in the tractor beam of the small screen. This is evident when Poole receives a celebratory Birthday transmission from his parents, an event to which he articulates no response at all.

"The World Tonight Sequence" anticipates the later sequence in which Bowman encounters and views subsequent versions of himself projected (or "broadcast") within a glowing, starkly lit, cube like structure (Figure 4) recalling the initial conceptualisation of the alien-artefact as TV-like cube (as identified by Pescovitz). The mise-en-scène, lighting and staging with its "confusing combination of styles" resembles a television set.

Barry Grant describes the sequence:

After the Stargate, Bowman appears in a room that looks, at once old and new, a confusing combination of Louis XVI and modern styles, where the

32 Thomas Allen Nelson, Kubrick: Inside a Film Artists Maze, Indiana, Indiana University Press, 2000, p. 123.

33 Stanley Kubrick Archive, University of the Arts, London, ref. no SK/12/3/4/3/19. 
astronaut confusingly watches himself die... In a detailed formalist analysis of this sequence, Mario Falsetto has shown how Kubrick's editing consistently subverts the viewer's understanding of narrative space by violating such normally inviolable techniques as the conventional shot/reaction shot... Each time Bowman sees another, more aged version of himself, we first see the new yet older Bowman from the physical point of view of the older but younger Bowman; but the next shot reveals that the earlier Bowman is no longer there. This apparent point of view shots cease to be point-of-view shots and their perspective -and ours, as viewers, becomes disembodied. ${ }^{34}$

Images of disembodiment and dislocation when set in proximity to the television recur across Kubrick's work (next section). Here Kubrick presents an aesthetically designed TV space for this process of disembodiment to take place in where the act of viewing the (self) image is foregrounded. Its confined 3 dimensional quadrilateral space and architecture also in direct contrast to the expansive, infinite cinematic space of the Stargate.

The Shining (1980) is Kubrick's most televisually rich work: TVs, TV watching and televisuality are embedded within the narrative and the Miseen-scène, architecture, style, and space of the film itself. Here I will consider, the film's US extended cut rather than the shorter, internationally theatrically released version as it exhibits a greater number of instances where television has a prominent presence and role. Archival research and an examination of an early draft of the script for The Shining from 1978, like the continuity scripts from 2001, further expose TV-centric moments of dialogue redacted from the final film (both versions).

At the start of the film, Jack phones home from the Overlook prior to his meeting with hotel manager Ullman, we cut to Danny and Wendy sat around the breakfast table in Colorado. Mirroring the breakfast sequence in 2001, Danny is engrossed in a cartoon being broadcast on an off-screen television while Wendy sits on the other side of the table reading Catcher in the Rye. This image is later communicatively relayed into Eyes Wide Shut during the sequence in which Bill Harford phones home from his office and we observe Helena engrossed in the television and Alice opposite her reading a newspaper. In each of these situations parent and child are detached, transfixed and unresponsive to the other's presence. Furthermore in The Shining, Wendy's statement to Danny that in going to live at the Overlook: "We're all gonna have a real good time" seems as programmed, automated and self-convincing as HAL's response to Amer during the interview when asked about the status of the mission: "It's all going extremely well thank you". In Eyes Wide Shut, the television itself acts as a physical barrier between Alice and Helena (Figure 13) coding the film's themes of the breakdown of familial communication.

34 Barry K. Grant, "Of Men and Monoliths: Science Fiction”, Gender and 2001: A Space Odyssey, in Robert Kolker (ed.), Stanley Kubrick's 2001: A Space Odyssey, NYC, OUP USA, 2006, p. 112. 
In this sequence Helena watches the Bugs Bunny cartoon The Fright Before Christmas (1979); in The Shining (extended cut), in one sequence we observe Danny watching a Roadrunner cartoon in a shot which follows the brief sequence of Halloran wending his way back along the snowy night time mountain pass to the Overlook. In the final image of Full Metal Jacket the young platoon advance across a hellish warzone yomping to the theme tune to The Mickey Mouse Club: "Who's the leader of the gang, the one for you and me?". Animated TV cartoons recur across Kubrick's films rendering the idea of childhood in crisis: the stability of Helena's childhood is threatened by the breakdown of her parent's relationship (and the first time we meet her she is palmed off onto a babysitter and asks to stay up watching television); Danny seems to find refuge from his own (abusive?) childhood trauma in the comic violence of Warner Brothers cartoons used meta-textually within the film's narrative when at the end of the film the lupine Jack becomes "Wile E. Coyote" to Danny's "Roadrunner"; and, the wholesomeness and all-American-ness of Disney's Mickey Mouse is set in contrast to both the dehumanisation of these young men, barely out of childhood, the destruction of innocence AND the unwholesomeness of the American presence in Vietnam. In a further example of intertextual, communicative relay, Helena's Bugs Bunny cartoon recalls Danny himself, whose pet name, as Halloran detects (through his mental connection with the boy) is "Bugs".

Tom Klein contextualises Kubrick's use of TV cartoon animation, citing Dr Alberta Stiegel's research into the effect of "violent" cartoons by animators and artists like Walter Lantz and Shamus Culhane:

Conventional wisdom prescribed that watching film violence was cathartic and would mitigate aggression in an audience. However, soon Dr. Siegel was famous for disputing this idea and the American press effusively covered the story. She launched a whole cottage industry of research-driven social science around media violence which endures to this day. The momentum for this concern was probably not that kids might imitate Woody [Woodpecker], but rather that a handful of skilled animation directors -Avery, Jones, Culhane, Hanna and Barbera- had pushed cartoons to such an outrageous level of notoriety... It was the adults who were shocked at their children's delight in seeing bombs, weapons, rockets, dropping anvils and unchained malice. ${ }^{35}$

During the sequence in which the Torrances travel to the Overlook they discuss the Donner Party, the pioneers in "Covered Wagon" times, who were trapped in the mountains during a savage winter and who, allegedly, turned to cannibalism ${ }^{36}$. After Wendy objects to Jack's mentioning of cannibalism to Danny, Danny states that "I know all about cannibalism, I saw it on TV". Jack

35 Tom Klein, "Stanley Kubrick and Violent Cartoons", Walter Lantz Archive, Cartoon Research, 22/08/2015. https://cartoonresearch.com/index.php/stanley-kubrick-and-violent-cartoons-1956/. Last Viewed: 22/11/2017.

36 Anticipating the situation the Torrances will later find themselves in. 
responds sarcastically “See, its ok, he saw it on the television!". This recalls Stiegel's influential research as well as further drawing attention to Kubrick's somewhat suspicious view of the medium. Here Danny's conditioning to TV violence is presented as an inverse to the enforced aversion therapy of $A$ Clockwork Orange.

The transmission of wireless broadcasting signals, communication and images occur throughout the film, and here we may observe the extended influence of Arthur C. Clarke's work on Kubrick beyond 2001: A Space Odyssey. Danny and Halloran, share a telepathic link in their ability to "shine". They are synchronous bodies for the broadcasting, relay and reception of a wireless signal, which in the archived 1978 script is described as a sort of electrical signal. Describing the sequence in which Halloran returns to the hotel, the script directions read:

\section{1 - SNOWCAT CAB - INT-DUSK-BP}

Halloran driving. Maybe he is being communicated to by both Tony and the hotel. The hotel causing electronic reverberate echoes in his skull, sinister phrases repeated over and over. ${ }^{37}$

Elmer Lower's earlier appraisal of Clarke's article: "All of the electrical energy needed to run the relay stations, according to the article, could come from the Sun" ${ }^{38}$ shares similarities with how Kubrick conceptualises the telepathic link as "electronic reverberations" relaying, transmitting and emanating from a central hub -in this case the Overlook hotel itself. This "wireless" link and relay between Danny and Halloran is foregrounded in the sequence in which Halloran lies on his bed at home watching the television and receives the transmission from Danny / Tony at the hotel, Danny appears to be undergoing a seizure or form of electric shock (Figures $\mathbf{5}$ and 6), this is heightened by tense, high pitched (electronic) tone. The twinning of Halloran and Danny is coded in the mise-en-scène and framing of the Halloran's bedroom where the television, reporting the blizzard is framed centrally between two table lamps on either side, we view the television from Halloran's perspective as it is framed also between his two feet (Figure 7). The "wireless" link between Danny and Halloran is also coded by the twin images in the symmetrically opposed paintings on opposite facing walls.

Kubrick's suggestion in the '78 script that "maybe he [Halloran] is being communicated to by both Tony and the hotel" has further implications. The extended U.S. Cut of the film contains a sequence in which we see Danny and Wendy watching a film, The Summer of 42 (Mulligan, 1971) on the television set in the hotel lobby. Danny is positioned at its feet, on the floor looking up, engrossed in its images; Wendy, is positioned further back on the couch, both are separated (again) by some distance (Figure 8). The TV is positioned absolutely 
centrally, dominating the frame (as it does in Halloran's bedroom) -it is on but not plugged in. It is afforded a ghostly, almost demonic presence, an embodiment of the hotel's control over the family, breaking it up. Kevin McLeod observes:

Television connects the film to The Summer of '42: an older child than Danny and a younger woman than Wendy flirt in the Kitchen and it combines with another scene in the film: the breakfast sequence mirroring Jack's breakfast in bed earlier, even coffee is poured (this TV is a mirror). 42 is a doubling of 21 ,

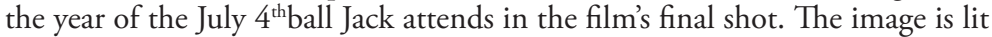
by the same light as Jack's transfixed solo previously (in the black sweater, the reverse on Danny and Wendy is no less contrasted... (if they are not careful the Hotel will absorb them as well)... the TV is a phantom of the hotel: there are no cables that connect it to a power source. ${ }^{39}$

TV's control over Torrance family life is further hinted at in the '78 script: after Ullman leaves, Jack comments (in dialogue redacted from both cuts of the film), "Well folks, I think we should go inside, get something to eat and make sure the TV works!". Television is a priority for the family. McLeod suggests that the TV is a "Phantom" of the hotel, but the hotel itself may be read as "phantom" and an embodiment of television. Danny spends a lot of time looking at screens, and he is established as a receptor for the (small) screened image. The archived '78 script directions indicate (during the games room sequence): "Pinball machines, electronic TV games, pool tables, table tennis. Danny is blasting away at a Star Raiders game..." ${ }^{\circ}$.

Earlier script directions read:

\begin{abstract}
DANNY'S VISION
"A Montage of shots which will include Jack talking to Ullman at the hotel, and the POV shot of the car driving up to the hotel. The Images are stylized in some special way. We will also see terrifying but unintelligible fragments of sinister violence at the hotel. We will not recognise the people involved, nor will we be sure what is happening." ${ }^{41}$
\end{abstract}

These fragmented bursts of violent imagery to which Danny is subjected recall the subjection of Alex to the intense bombardment fragmented violent imagery in A Clockwork Orange. During The Shining's games room sequence Danny encounters the Grady twins for the first time, they are the first image relayed and broadcast by the hotel and their repeated "Come and Play with us Danny..." becomes akin to a televisual catchphrase. Later it is used in proximity to the dramatic jump cut to their mutilated bodies, recalling the juxtaposition of children, play and violence signified through Kubrick's interest in animation. The Hotel is a broadcaster, a transmitter of the image, and each of

39 Kevin McLeod, Physical Cosmologies: The Shining. http://www.mstrmnd.com/log/960, not date available. Last Viewed: 22/11/2017.

40 Stanley Kubrick Archive, University of the Arts, London, ref. no. SK/15/9/17-31.

41 Ibid. 
the Torrances become receiving satellites in the final third of the film, orbiting the hotel, picking up its transmissions. This is not only true of Jack but also of ("confirmed horror movie addict") Wendy, who receives a range of "broadcast images": the "Manbearpig" and the "Guest" framed through a hotel room doorway; the party guest with the axe wound to the head; and in the film's extended cut the Bunuelian skeletons in the deserted space of the ballroom (Figures 9, 10 and 11). Ghosts, after all, may be read as synonyms for the television $^{42}$ : simultaneously present and absent, an image or imprintand were recognised as such in the work of the British sci-fi / horror television writer Nigel Kneale ${ }^{43}$. These images are part of the hotel's violent narrative and each of the Torrances are in danger of being "absorbed" or written into it (as Jack is shown to be at the end, in the final "Photograph" shot).

The film's mise-en-scène also offers further evidence of the film's televisuality: the yellow carpet of the corridor which extendd into the hotel ballroom (Figure 12) is patterned with squares, inside of which appear to be stars: TV-like glowing cubes, an image again observed in the light fitting illuminating the maze in the film's finale and recalling the original conceptualisation of the Monolith in 2001: A Space Odyssey.

In the article "Ted Kramer Has A Nightmare" Greg Keeler draws critical comparison between The Shining and Kramer Vs. Kramer (Benton, 1979):

In The Shining Daddy has lost his job and has been forced to find a new one, but this time the original job was not so glamourous (an English teacher) and the new job is shaky to say the least (an erstwhile novelist-come-caretaker. And Mom, Mrs Torrance, perhaps more realistically has chosen not to abandon the little tyke for a brilliant career, but to stick out and help Dad with his. ${ }^{44}$

With The Shining reduced down in this way, the family-driven narrative of the domestic television drama begins to emerge. Eyes Wide Shut also exhibits an identifiable televisual identity in its privileging of the home-space and its domestic interior; its family narrative (the breakdown of communication,

42 The term "Ghost" has particular televisual resonance. "Ghosting" according to Jorma Hyypia ("Beating Interference", Popular Mechanics, June 1980, p. 126) refers to a replica of the TV image, offset and superimposed on top of the actual broadcast video image, it's caused by the TV signal making its way to the antennae by two different paths causing problems in the time of its arrival. It causes the image to become distorted, uncanny.

43 Kneale is a recognised influence over author Stephen King and certainly a figure Kubrick might have been aware of (the influence is certainly felt in The Shining). His TV plays deals with the Ghost/TV image juxtaposition and with television as a haunted space. This is most clearly evident in the 1972 BBC2 television play The Stone Tape in which the spectre of a maid servant is pronounced as is through a degraded video image -this has also been noted By Stacey Abbot and Lorna Jowett, TV Horror: Investigating the Darker Side of the Small Screen, London, I.B. Tauris, 2013, p. 94.

44 Greg Keeler, "Ted Kramer Has a Nightmare”, Journal of Popular Film and Television, Vol. 8, 1981, p. 3. 
tensions in the family unit, infidelity) is broadly soap-operatic. The Shining and Eyes Wide Shut are almost companion pieces in Kubrick's cinema presenting a more intimate, (more claustrophobic?) form of family drama: and the breakdown of the family "machine" (a Kubrickian trope observed across the canon of Kubrick's work from 2001).

Towards the beginning of Eyes Wide Shut Kubrick presents an establishing shot of the outside of the Harford's luxury apartment block. We then cut to the interior where Bill and Alice are getting ready to leave for Ziegler's party and where Bill is looking for his wallet. This establishing shot also borrows from another televisual trope, used particularly in the (family-driven) sitcom format (e.g. Establishing shots of "Monk's Coffee Shop" in Seinfeld) which, as Andrew Costa was once a ubiquitous part of the visual lexicon of the television sitcom, its presence now diminished:

Today, the establishing shot is a thing of the past. Often viewed as tasteless and passé, modern sitcoms like HOW I MET YOUR MOTHER and THE BIG BANG $T H E O R Y$ resort to sound cues or quick visual transitions to seamlessly bring the viewer from one location to another. Long gone are the days of "upward tilt on tall building," "shot of school with sound of bell ringing" or crowd favourite, "slow zoom into bedroom window... 45

As with The Shining, televisions have a significant presence throughout Eyes Wide Shut (I earlier discussed the film's breakfast table sequence). In one sequence, Alice asks Bill to wrap Christmas presents with her, a festive and joyful family task, he declines, deferring the moment. Prior to this Bill is framed at a right-angle to the television, staring past it, distracted while it plays the football. Later when he calls Alice from the prostitute Domino's flat, a television, this time turned, significantly, off (this is unusual in a Kubrick film -TV's are always on!), is present in the back ground: Bill appears to connect to Domino in a way he does not to Alice. However, Alice (on the other end) is again framed around the breakfast table where the television is showing the 1973 film Blume in Love directed by Paul Mazursky, star of Kubrick's first film Fear and Desire (in another example of TV's self-reflexive presence in Kubrick's cinema). Throughout TV is placed in proximity to instances where the family seem least connected to each other. Although neither Alice nor Bill appear to engage with the images on the television sets, its in-shot presence seems to subdue, distract and sedate. If in The Shining, TV has an almost supernatural presence and hold over family life, in Eyes Wide Shut its fulfils a similar role and becomes a coded signifier for the fragmentation of the family unit.

45 A. Costa, The 90s Sitcom Establishing Shot-A Dying Art Form, 23/11/2010. https://stevebuscemifanfiction.wordpress.com/2010/11/23/the-90s-sitcom-establishing-shot-a-dying-artform/. Last viewed: 22/11/2017. 


\section{Kubrickian Design in contemporary television: "This is my design"}

Having discussed the significant role television plays within Kubrick's cinema, I would like now to demonstrate Kubrick's position at the interface of the two mediums by interrogating the increased role and presence of Stanley Kubrick in contemporary quality, ("spectacular") TV auteur-led drama. ${ }^{46}$

In the drama The Path (2015, Amazon Prime) for instance, a man, the founder of a cult ("movement"), the aim of which is to transcend through the threshold of "The Light", lies dying in a starkly lit hospital bed. The man in question is played by Keir Dullea, the scene a deliberate homage to the ageing, dying Bowman in 2001: A Space Odyssey (Figures 15 and 16). In the recent $\mathrm{BBC}$ regency costume drama Taboo (BBC, 2016) the staging, use of symmetrical space, one point perspective, set design, and internal lighting recalls Kubrick's own revisionist take on the costume drama in Barry Lyndon (1975). Taboo, part of a post-Downton Abbey, re-interrogation of the genre makes uses of staged, symmetrically spaced tableaux/mise-en-scène, like Barry Lyndon, its staging and imagery is "Spectacular" (as Helen Wheatley has defined the term (Figure 17).

If Kubrick is currently undergoing a cultural renaissance then his influence has been "cultural rather than cinematic" ${ }^{47}$ and that he has not enjoyed the same "deep seepage" of influence in cinema as, for example, Robert Kolker suggests Hitchcock has, then it may be argued that, in fact, increasingly modern cinematic television is increasingly looking to Kubrick -not simply as a point of homage and pastiche but as a template for set design and miseen-scène, complex and maze like narratives, images that challenge and test the borders and parameters of televisual space and narrative.

De Valck and Teurlings maintain that:

Within Television Studies there seems to be a growing consensus that television as we know it is irrevocably changing. Some are gleefully announcing the death of television, others are less sanguine but insist that television is changing before our eyes. Paradoxically, the question "What is television?" has gained relevance as the medium falls into demise. ${ }^{48}$

Television, has since its inception been under a constant state of technological and artistic change, experimentation and evolution. The current milieu of cinematic television has been made possible by the evolution of home viewing technologies and the cinematic aspiration and scope of contempo-

46 I will be expanding this part of the discussion in a future publication.

47 Robert Kolker, "Rage For Order: Kubrick's Fearful Symmetry", in Raritan: A Quaterly Review, Summer 2010, Vol. 30 (1), p. 53.

48 Marijke De Valck and Jan Teurlings, After The Break: Television Theory Today, Amsterdam, Amsterdam University, 2013, p. 8. 
rary, design-led television has seen a vanguard of Kubrick-influenced film auteurs venturing into the medium: David Lynch pioneered the way with Twin Peaks in the 1990. Lynch's presentation of the austere, uncanny and surreal Black Lodge with its zig-zag patterned carpet design and minimalist, extradimensional "other" space: "The Red Room, owes an aesthetic debt to the early $20^{\text {th }}$ century modernist designs of architect Josef Hoffman, whose own designs are part of the production design research for Kubrick's The Shining contained in the Stanley Kubrick archive".

Part of the criteria for $21^{\text {st }}$ century notions of "Quality" in television is inter-textuality and self referentiality, it calls into question pre-suppositions of what television is and what it's potential is. Hence Kubrick, is an apposite point of reference for writers, showrunner and producers of this televisual milieu. In Italian auteur Paolo Sorrentino's stylised The Young Pope (a 2016 global cross production between Sky Atlantic, HBO and Canal+), the newly elected Pontiff Pius XIII (Jude Law) offers Vatican Marketing Chief Executive, Sofia, a litany of "most important" $20^{\text {th }}$ century cultural icons: Salinger, most important author; Daft Punk, most important electro music act; contemporary artist, Banksy. He asks her "Most important film director?" To which she answers "Spielberg". "No" he corrects her "Kubrick". What do these icons have in common? What connects them all? They kept themselves hidden behind their work, and rarely if ever allowed themselves to be seen in public.

The presence of Kubrick on this list is of interest for a couple of reasons: firstly we may an in-joke: Jude Law played the robot escort Gigolo Joe, of course, in Spielberg's 2001 film A.I.: Artificial Intelligence, a film with a long and troubled production history ${ }^{49}$. In that film Kubrick's presence is felt but hidden behind that of Spielberg's. Pope Pius's claim is true and deliberately recognises the increasing presence of Kubrick hiding behind both the narratives and visual style of contemporary television drama. The Pope's claim may be read as a statement by Sorrentino himself who invites us look for Kubrick within his own shooting of the Vatican interiors. Kubrick's "spiritual" presence is felt throughout the series, hidden but always there in terms of staging, composition, lighting and use of space which recalls, in particular both Barry Lyndon and 2001: Space Odyssey.

Luke Ottenhoff observes the presence and influence of Kubrick in The Young Pope:

Kubrick's movies often centred on a deep, gnawing fear or unease, prompting the question, the unifying thread, that runs through his films: is fear the underlying energy of human affairs? It's there from Paths of Glory to Dr. Strangelove to Eyes Wide Shut. But Kubrick didn't always pose it to us in an

49 Explored in depth by Peter Kramer in the article "Adaptation as Exploration: Stanley Kubrick, Literature and A.I.: Artificial Intelligence", Vol. 8, No. 3, August 2015, p. 373. 
obvious, in-your-face way; his was a more manipulative, slight-of-hand-style craft, which made us think things without him telling us to think them. It's become increasingly clear that Paolo Sorrentino's affecting, remarkably fascinating series The Young Pope shares many of these Kubrick-isms. ${ }^{50}$

Hannibal (NBC, 2013-15) Bryan Fuller's contemporary gothic, guignol and experimental interpretation of the novels Thomas Harris, homage's Kubrick $^{51}$ in the use of space, design and staging of tableaux. Furthermore showrunner Bryan Fuller has openly acknowledged the show's debt. In interview with Vulture he offers:

[Director] David Slade and I had long conversations about the Kubrickian feel of the show. We are telling the story of a man who makes his living from his imagination and who slowly loses his mind over the course of the show... We are telling a version of The Shining except that this guy is not an alcoholic. ${ }^{52}$

He continues:

I understood watching it [The Shining] as a ten year old that this was psychological story telling. ${ }^{53}$

While Hannibal openly acknowledges Kubrick's debt through homage, more broadly its experimentation with the dimensions and symmetry of the televisual space, the spatial arrangement of characters (in Hannibal Lecter's office the profile of doctor and patient mimics the Kubrickian trope of seating characters in profile, facing each other); its recurrent use of grotesque tableaux / staged murder scenes (one particularly grisly tableaux recalling the framing of Halloran's bedroom in The Shining, Figure 18) and minimalist aesthetic confer upon it the "spectacular" nature Kubrickian cinema.

In season 3 of the show Hannibal's cell deliberately recalls the Louis XVI room towards the end of 2001: A Space Odyssey (Figure 19). Furthermore, profiler Will Graham's mantra when embodying the space of the psychological space of the killer and when confronted with said tableaux is "This is my design", reminding us not only of the show's own use of "spectacular" architectural (often Brutalist) design, but also of Kubrick's own concern for design in the films. The Kubrick Archives contain folder upon folder, box upon box of detailed design and production research carried out for each film -pages and cut out from design magazines, architecture journals, car magazines, etc.

50 Luke Ottenhoff, “The Young Pope is Kubrick for Millenials”, A. Side, 13/2/2017. http://ontheaside.com/culture/the-young-pope-is-kubrick-for-millennials/. Last Viewed: 22/11/2017.

51 Not least in Season 3, Episode 5: "Contorno", in which a violent, climactic fight between Jack Crawford (Laurence Fishburne) and Hannibal Lecter (Mads Mikkelsen) is staged in slow motion to the overture from Rossini's opera, The Thieving Magpie, A Clockwork Orange.

52 Zach Dionne "Bryan Fuller Explains Hannibal's Nod to The Shining", Vulture, 5/05/2013. http://www.vulture.com/2013/04/bryan-fuller-explains-shining-homage.html. Last Viewed: 22/11/2017.

53 Ibid. 
TV Dramas like Hannibal and Westworld (HBO) offer a series of (tele) visual puzzles, "Easter eggs", to engage the viewer. Like Danny in The Shining the viewer is encouraged to follow a trail of "sweets" and in the case of Westworld offered an actual maze to navigate. In his paper "Inside the Interpretive Maze of The Shining" Vincent Jaunas ${ }^{54}$ suggests that in The Shining the maze is at the centre of a narrative that is full of mazes (the hotel itself stands a maze). The Maze is a trope, a signifier of Kubrick's invitation to the viewer to the enter the Maze (the hotel; film itself), to willingly become lost in it, to navigate it's impossible corridors, and in doing so to unpack its various textual and aesthetic meanings:

The omnipresence of the motif of the maze may thus convince the most tenacious spectators that if they keep digging beyond the surface, they may eventually reach a hidden centre and unlock a secret reading strategy that would turn the film into a limpid message... the maze of The Shining suggests that there is no hidden centre, no secret key which would unlock all its mysteries and provide a clear reading. As Roger Luckhurst wrote, "one must chart the structure of the maze rather than arguing there is only one way through it". However, in The Shining, the obsessive hermeneutic craze of the spectator seems to be encouraged as well as challenged, so that one runs the risk of getting lost in an interpretative dead-end. By creating a film-maze, Kubrick integrated the spectator's quest for meaning at the core of his aesthetics, to better question it. ${ }^{55}$

Westworld, an "adaptation" (another Kubrickian trope, like Hannibal) of the 1973 film directed and written by Michael Crichton and starring Yul Brynner, centres around a Wild West themed theme park' where human guests interact with artificial intelligence so authentic as to be undetectable from real people; a space where total authenticity is set in tension with artificiality and where A.I. eventually attempt to break their programming and rebel $^{56}$. Guests are able to engage with an environment which is both real and televisual. At the centre of the "Gamespace" 57 and "Parody Space" 58 is a metatextual maze to be navigated, and to which Ed Harris's psychopathic (human) gunslinger is on a quest to find its centre, where, it is revealed, his prize will be self-knowledge and understanding, a search for meaning. Like Kubrick's "Hermeneutic" "film- maze" in The Shining so Westworld offers "TV-Maze" in which viewers are asked to conquer the "maze" of the programme itself.

54 Film scholar, Kubrick researcher and co-convener of the conference Stanley Kubrick, Nouveaux Horizons, Université Bordeaux Montaigne, 16/05/17 - 17/05/17.

55 Vincent Jaunas, "Inside the Interpretive Maze of The Shining", in Vincent Jaunas and JeanFrançois Baillon, op. cit., 2018, p. 76.

56 Kubrick's films are full of children who attempt to break their programming: HAL, Alex, Private Pile, even David in Spielberg's 2001 “adaptation" of Kubrick's own unmade A.I.: Artificial Intelligence.

57 Stephen Mamber, "Kubrick in Space", in Kolker R. (ed.), 2001: A Space Odyssey, New Essays, NYC, OUP USA, 2006 p. 58.

58 Ibid., p. 59. 
Westworld, also offers a juxtaposition between "game space" and "Institutional-official space" technocratic hub of authority, brings to mind the "War Room" in Dr Strangelove. Furthermore in S1E2, William, a guest, crosses from one apparently sealed-off space to the other down a starkly lit corridor (recalling Bowman in 2001: A Space Odyssey) through a large black door, which resembles nothing less than the Monolith (Figure 20). Upon going through the door, he then experiences a dramatic cut in time (2001) finding himself in the starkly contrasting saloon of a wild west bar.

The emphasis on design in both Hannibal and Westworld, engages similar Kubrickian concerns in terms of their mutual emphasis on cinematic/televisual design and the interrogation of Human design (this illustrated in the opening titles to Westworld which offers image of mechanised, industrial design) (Figure 21).

In conclusion I have tried to reveal Kubrick's place at the interface of two mediums: television and film. Television has a significant, complex, presence as a self-reflexive device in Kubrick's cinema, and I have attempted to understand and theorise Kubrick's own complicated relationship to the medium via a close reading of a selection of films. Furthermore I have attempted to show how Kubrick is starting to be appropriated as a key stylistic and textual point of reference in contemporary design-led, cinematic "Quality" TV drama, part of the vernacular of contemporary "spectacular" television itself.

\title{
Dr Matthew Melia
}

Kingston University, UK

M.Melia@kingston.ac.uk

\begin{abstract}
This essay explores and posits Stanley Kubrick's relationship to the medium of television through a close reading of a selection of films (2001, The Shining and Eyes Wide Shut) and an analysis and observation of the presence of televisions, the act of television watching and the appropriation of TV aesthetics into this most cinematic of oeuvres. This is the first time such a study has been undertaken and the essay draws upon a body of research carried out at the Stanley Kubrick Archive, London. In part 2 of the essay, I further examine the position of Kubrick at the interface of film and television by offering critical discussion of the current Cinematic, auteur led "Spectacular" TV revolution and Kubrick's status as a key point of stylistic reference, homage and appropriation.
\end{abstract}

\section{Keywords}

Kubrick, television, communication, broadcast, inter-textuality. 


\section{Résumé}

Cet article envisage la relation entretenue par Stanley Kubrick avec le médium télévisuel à travers l'analyse détaillée de trois de ses films (2001, Shining et Eyes Wide Shut) ainsi que l'étude et l'observation quant à la présence de télévisions, de personnages regardant la télévision et de l'appropriation de l'esthétique télévisuelle dans cette œuvre si cinématographique. Cette approche est inédite et se base sur un ensemble de recherches effectuées aux Archives Stanley Kubrick de Londres. Dans une seconde partie, nous examinons la position kubrickienne à l'interface du cinéma et de la télévision en proposant une discussion critique centrée sur l'actuelle révolution télévisuelle, davantage spectaculaire et auteuriste, et sur le statut central de Kubrick, générant références stylistiques, hommages et appropriations.

\section{Mots-clés}

Kubrick, télévision, communication, médias, inter-textualité. 


\section{BIOGRAPHICAL NOTE}

Matthew Melia is a senior lecturer in film and TV at Kingston University, UK. He has research interests in the work of Kubrick and Ken Russell and the role of space and architecture in visual culture. His PhD was on Architecture and Cruelty in the work of Samuel Beckett, Antonin Artaud and Jean Genet. 


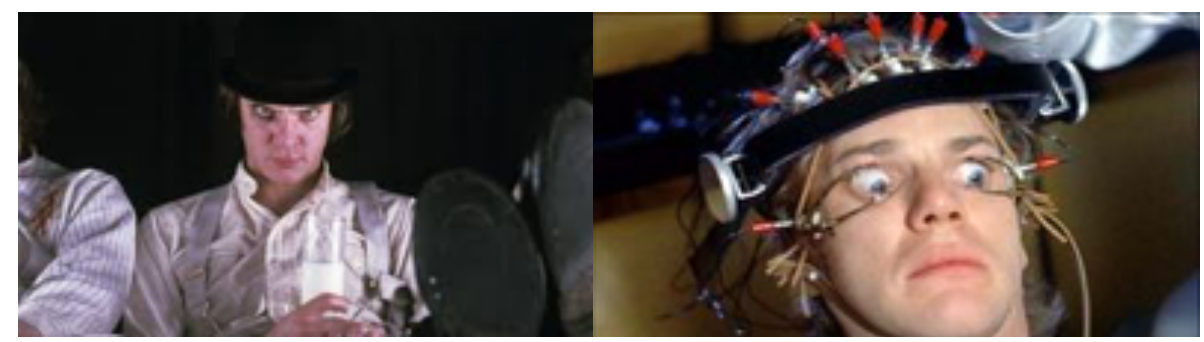

Figure 1

Figure 2

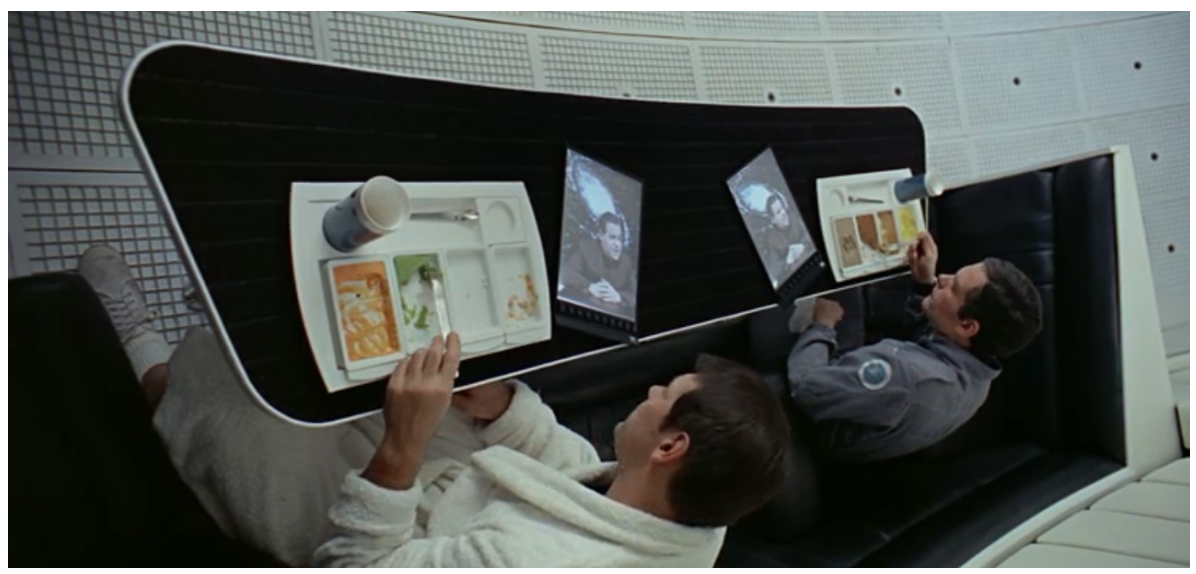

Figure 3

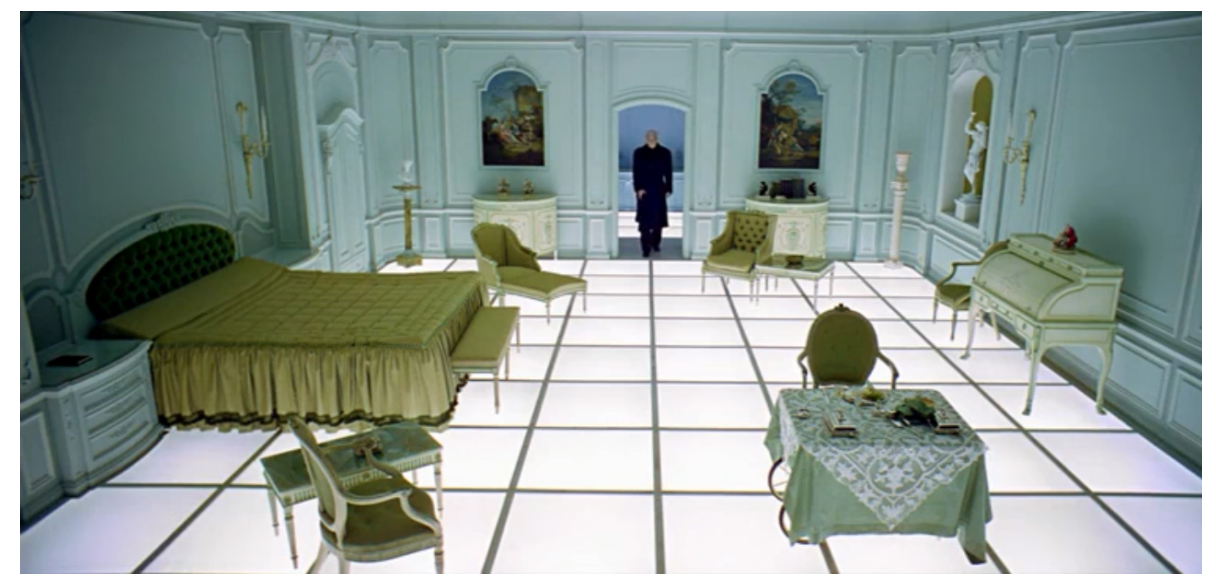

Figure 4 


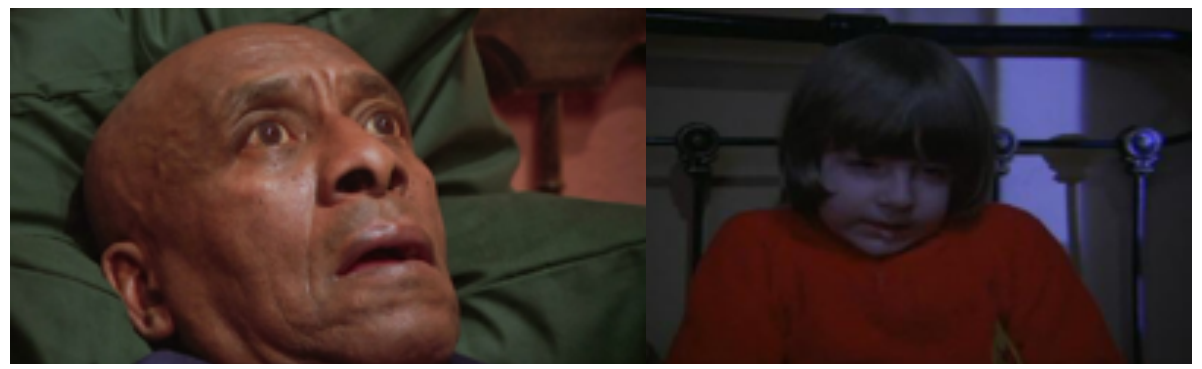

Figures 5 and 6

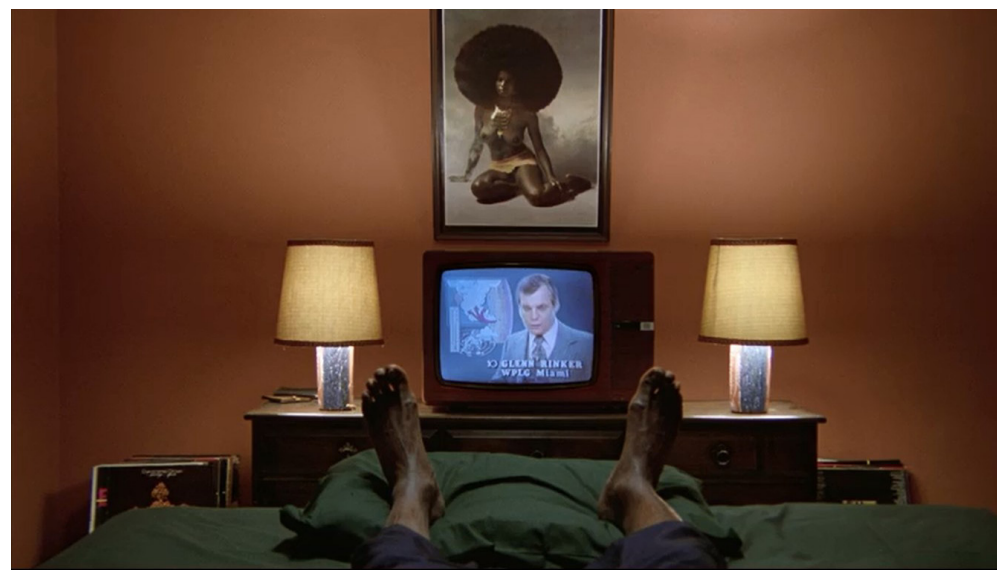

Figure 7

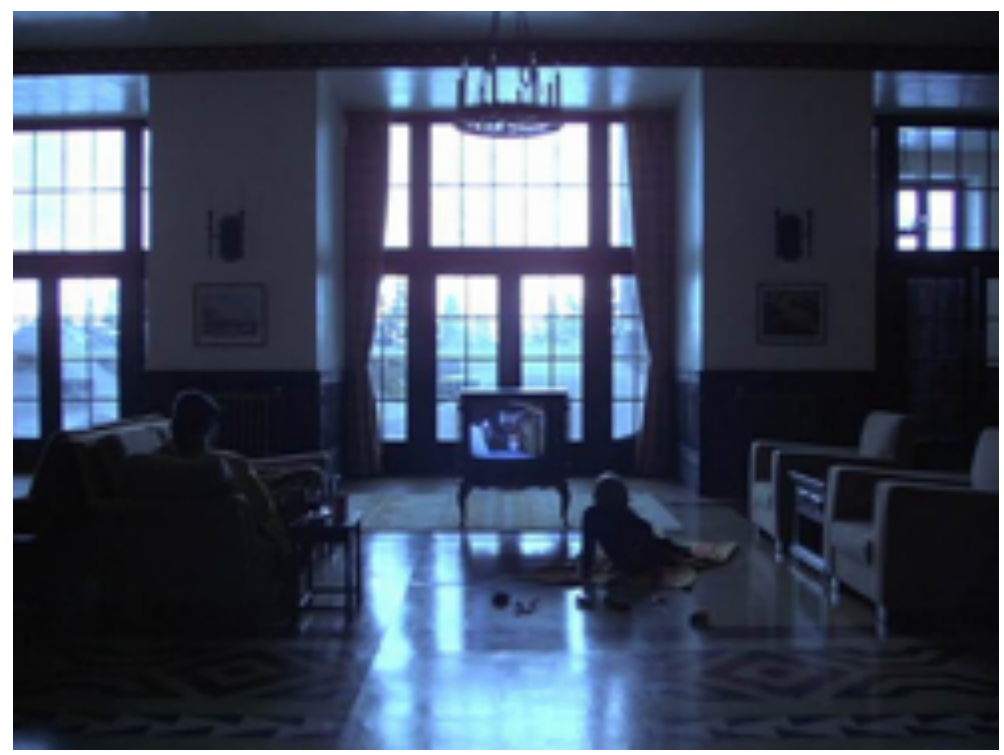

Figure 8 


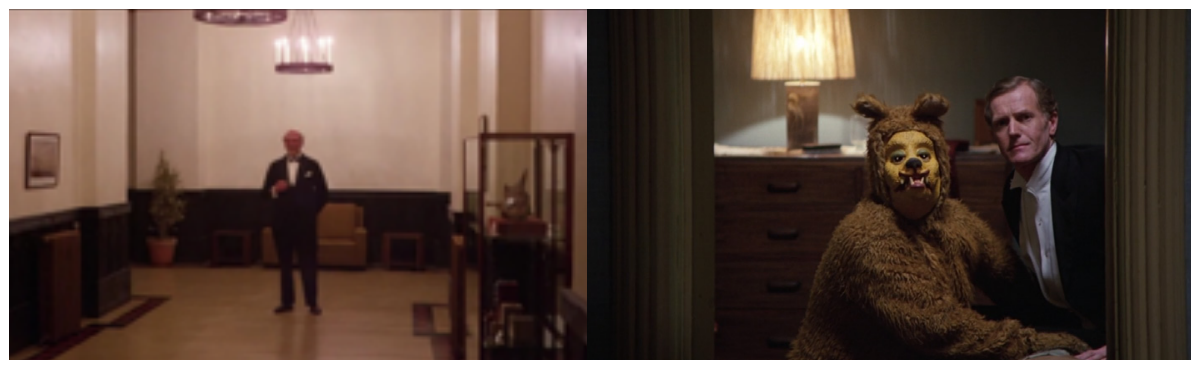

Figure 9

Figure 10

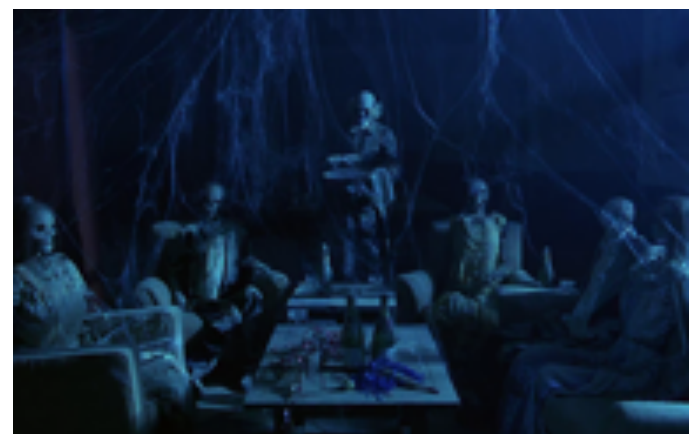

Figure 11

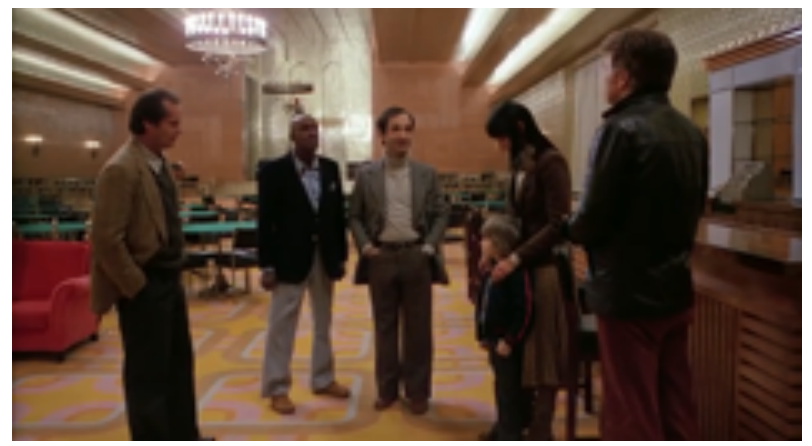

Figure 12

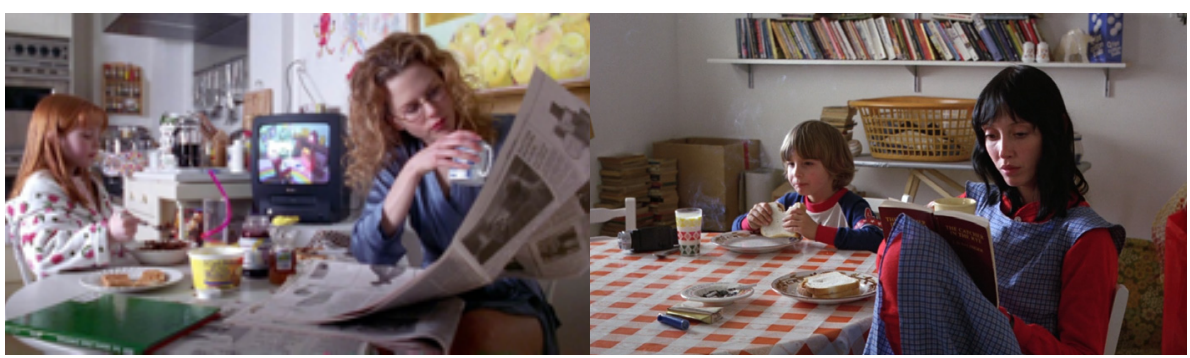

Figure 13

Figure 14 


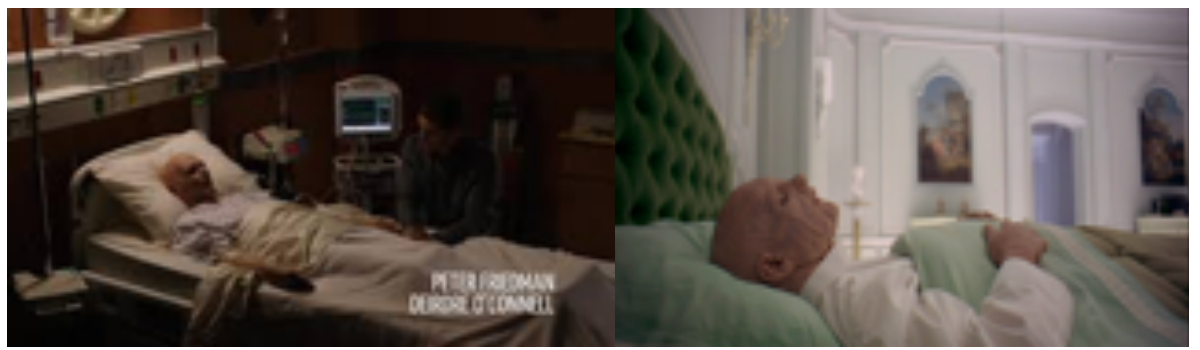

Figures 15 and 16

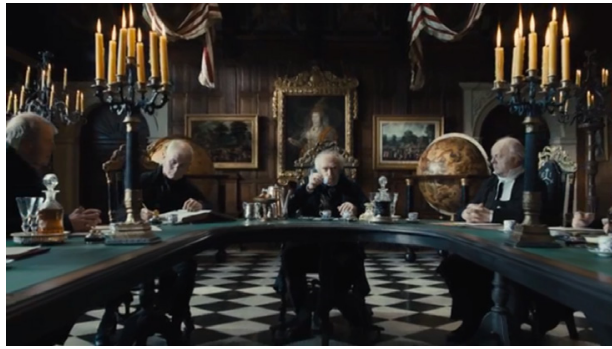

Figure 17

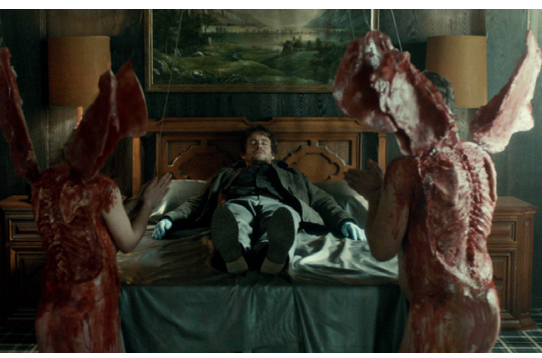

Figure 18

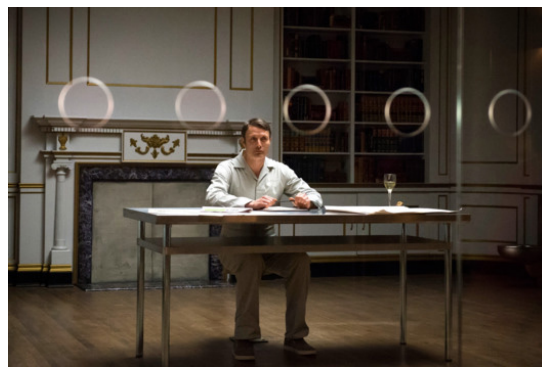

Figure 19

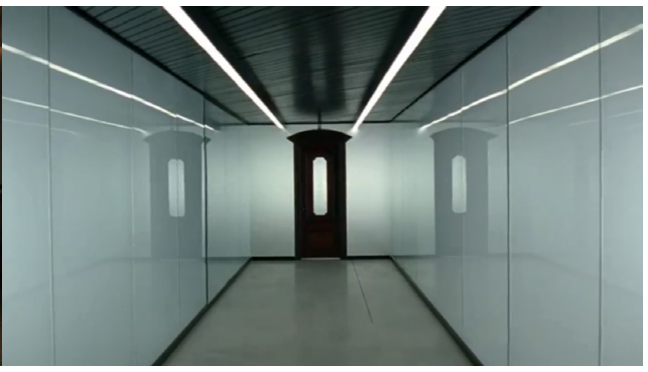

Figure 20

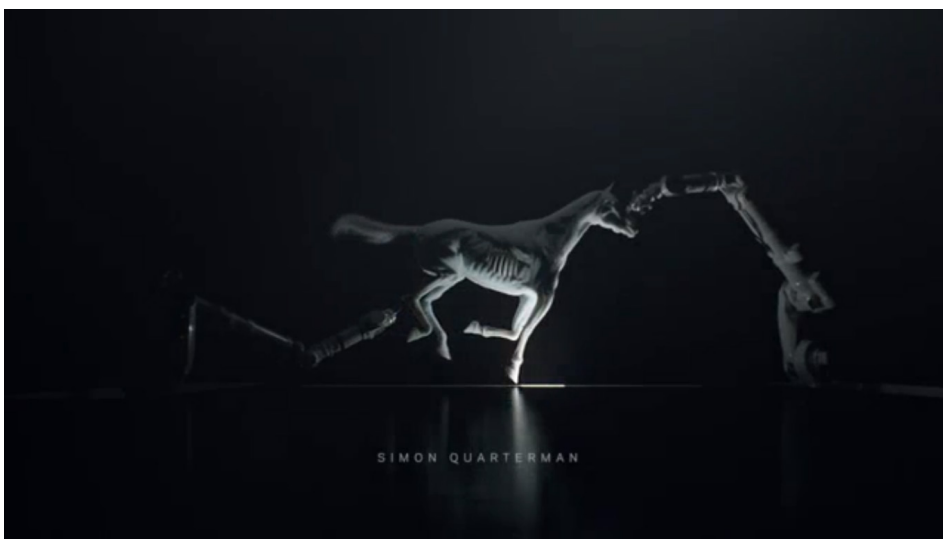

Figure 21 